\title{
Building, Dwelling, Dying: Architecture and History in Pakistan
}

Chris Moffat, c.moffat@qmul.ac.uk

School of History, Queen Mary University of London

Published in Modern Intellectual History (2020)

\section{Abstract}

There is a long history of scholars finding in architecture tools for thinking, whether this is the relationship between nature and culture in Simmel's ruins, industrial capitalism in Benjamin's Parisian arcades, or the rhythms of the primordial in Heidegger's Black Forest farmhouse. But what does it mean to take seriously the concepts and dispositions articulated by architects themselves? How might processes of designing and making constitute particular forms of thinking? This article considers the words and buildings of Lahore-based architect Kamil Khan Mumtaz (b.1939) as an entry-point to such questions. It outlines how professional architecture in Pakistan has grappled with the unsettled status of the past in a country forged out of two partitions (1947 and 1971). Mumtaz's work and thought - engaging questions of tradition, authority, craft and the sacred - demonstrates how these predicaments have been productive for conceptualising time, labour and the nature of dwelling in a postcolonial world. 


\section{Architecture and History}

Pakistan as place and idea poses some provocative problems for the philosophy and anthropology of history. Established in 1947 less than a decade after its emergence as a political goal, the sovereign state of Pakistan represented a rupture in South Asian history. Premised on separatist claims to 'nationality' status, it was also a break from historical forms of Muslim political thought and identity in the region, which had in the early twentieth century gravitated toward ideas of imperial pluralism, elite stewardship or the possibility of minority status within a broader community. ${ }^{1}$ The postcolonial polity carved out of colonial India would fracture again in 1971, when a mass movement in the country's eastern wing fought an independence war to establish Bangladesh. The intellectual history of Pakistan has been characterised accordingly by questions of separation, loss and mourning but also of futurity and the possibilities afforded by rupture and renewal. ${ }^{2}$ The nature of the relationship between past, present and future has been subject to considerable contestation in Pakistan, explored by philosophers, poets, religious thinkers, and, as I argue in this essay, architects. ${ }^{3}$ Architects, in their thought and practice, attend to complex problems of time and historicity. Designing and building in Pakistan necessitates a confrontation with the unsettled potential of the past characterising this context.

\footnotetext{
${ }^{1}$ Faisal Devji, Muslim Zion (London, 2013), especially Chapter 2. On the history of qaum in South Asia, see the 'Introduction' to Ali Usman Qasmi and Megan Robb, eds., Muslims Against the Muslim League (Delhi, 2017).

2 Devji, Muslim Zion; Naveeda Khan, Muslim Becoming (Durham, NC, 2012).

${ }^{3}$ See Chris Moffat, "History in Pakistan and the Will to Architecture", CSSAAME 39:1 (2019), 171-

83, and Javed Majeed, “Everything Built on Moonshine” (Forthcoming).
} 
The professionalization of architecture in the modern world has placed questions of history at the heart of both its training and practice. ${ }^{4}$ What should architects learn from the past, if anything? What value is the 'canon' of great architecture, and who is to be counted among its protagonists? How should new buildings and structures relate to existing cultural patterns and local traditions? Different schools of architectural thought can be distinguished by their attitude toward such questions. The polarisation provoked by the Modern Movement was in part due to its attempt to break from history - to create "an architecture in which the old codes have been overturned"5 - with figures like Le Corbusier, Walter Gropius and Mies van der Rohe approaching new materials and new technologies as the means to create a new world. ${ }^{6}$ But even this rejection of the past required mastery over that which came before - consider Le Corbusier's appeal to "the lesson of Rome."7 The architect's awareness of their place in the history of architecture is an important aspect of their claim to expertise. Courses designed to inculcate historical consciousness (often paired with field trips to historical sites) remain standard in architectural schools around the world, and reflexivity provides one of the ways professional architects distinguish their work from other forms of building - whether the pragmatic efficiency of the

\footnotetext{
${ }^{4}$ Spiro Kostof, ed., The Architect (Berkeley, 2000); Dana Cuff, Architecture: The Story of Practice (Cambridge, Mass., 1992).

${ }^{5}$ Le Corbusier, Towards a New Architecture (New York, 1986 [1931]), 7.

${ }^{6}$ For an evocative assessment of this moment, see Reyner Banham, Theory and Design in the First Machine Age (London, 1960).

${ }^{7}$ Le Corbusier, Towards..., 173.
} 
temporary shelter, the do-it-yourself innovations of the self-build, or the ambitious structural visions of the engineer.

The consolidation of the profession in Pakistan, which began in earnest in the late 1950s with government investment in technical education and which only achieved legally regulated status in 1982, has been dominated and enlivened by such debates. ${ }^{8}$ What could or should new architecture look like in this future-oriented, post-colonial country? How might architecture contribute to a project of unity in a polity forged out of refugees and strangers, internally fractured by divisions of language, ethnicity, sect, caste and class? Should a 'national' architecture emerge from or break with historical and 'traditional' modes and styles of building evident at local and regional levels? To what extent should the Western script of architectural history be used in education and training? Should a state for Muslims privilege 'Islamic architecture', and if so, how should this be defined? What specific skill-set does it require?

The unresolved status of these questions is reflected in Pakistan's varied built environment, where monumental pre-colonial structures are juxtaposed with modernist concrete and colonial red-brick complexes are shadowed by steel and glass towers inspired by twenty-first century Gulf aesthetics. The early decades of the post-colonial state saw foreign architects and planners commissioned for their skill and attendant prestige - famously with CA Doxiadis' design for Islamabad or Michel Écochard's Karachi University - but by the 1970s a new generation of locally or internationally trained Pakistani architects were making their mark. Private practices established in major urban centres

\footnotetext{
${ }^{8}$ See the Ordinance for Pakistan Council Architects and Town Planners, with associated documents, in Cabinet Division File No.138/Prog/81, National Documentation Wing, Islamabad.
} 
competed or collaborated with the triumvirate of building services established by the central government in 1973: National Engineering Services Pakistan (NESPAK), Pakistan Environmental Planning and Architectural Consultants (PEPAC), and the National Construction company (NC). The sprawling, top-down efforts of such bodies are contrasted with the great variety of unplanned, informal constructions of brick, cinder-block, corrugated cladding or tarp that pepper Pakistani cities, towns and villages, occasionally well-established but often temporary and merely tolerated, as where a cluster of residences assembles in the space next to a construction site, housing its transient workers. It is estimated that 35 per cent of urban populations in Pakistan live in such makeshift 'katchi abadis'. ${ }^{9}$

The manner in which individual architects navigate this landscape in their designs and in their buildings can reveal much about the significance of history, the possibilities accorded to space, and visions of the future in contemporary Pakistan. The anthropologist Victor Buchli writes that "buildings are about thinking and working through things that cannot be adequately cognized and presenced in the here and now: the past, the future, ancestors, resolutions of social conflict, and contradiction." They can also be about imagining what is not there, or "what cannot possibly be physically or conceptually realized as being there", from communist utopia to the ideal nuclear family to the 'primitive hut'.10 There is indeed a long tradition of scholars finding in architecture tools for thinking, whether this be the relationship between nature and culture in Georg Simmel's ruins, commodification and industrial capitalism in Walter Benjamin's

\footnotetext{
${ }^{9}$ Aasim Sajjad Akhtar, Politics of Common Sense (Delhi, 2018), 152.

10 Victor Buchli, An Anthropology of Architecture (London, 2013), 167.
} 
Parisian arcades, or the rhythms of the primordial in Martin Heidegger's Black Forest farmhouse. ${ }^{11}$ But it is also important to take seriously the concepts, ideas and dispositions articulated by architects themselves. This necessitates an understanding of designing and making as particular forms of thinking, a relationship between the mind and the hand that facilitates insights into the matter of time, work, space and being.

This article focuses on the career of one of the most thoughtful navigators of Pakistan's built environment, the Lahore-based architect Kamil Khan Mumtaz (b.1939). With the help of Mumtaz's words and buildings, I demonstrate how the predicament of an 'unsettled' relationship to the past has been productive for thinking about time, labour and the nature of dwelling in Pakistan. In one sense, Mumtaz belongs to a wider generation of architects across the postcolonial world who confronted the limitations of international modernism in the 1960s and 70s, attempting to develop a style and method more 'appropriate' for their particular contexts. But the solution Mumtaz arrived at has been more radical than that of his peers, in part because it seeks to dissolve the authority of the architect and invert dominant ideas of creativity, innovation and production. Tracing Mumtaz's engagements with history and the question of 'tradition' within the territory of Pakistan, I describe his arrival at a particular approach to building and his advocacy of a specific disposition towards time, one infused with ideas of the sacred but also the dignity of work and the value of patience. I

\footnotetext{
${ }^{11}$ Georg Simmel, 'Two Essays', The Hudson Review 11:3 (1958), 371-85; Walter Benjamin, The Arcades Project (Cambridge, MA, 1999); Martin Heidegger, 'Building Dwelling Thinking' in Poetry, Language, Thought (New York, 2001), 141-60; see also Adam Sharr, Heidegger's Hut (Cambridge, MA, 2017).
} 
consider what this means for understanding architectural practice as a mode of engagement with time and history, connecting this to debates about the nature of building in the modern world but also understanding it as an intervention into the faultlines of Pakistan's $21^{\text {st }}$ century present.

In the largely unwritten history of Pakistani architecture, Mumtaz is one of a number of figures distinguished by their reflexivity on practice, their engagement with the past, and their navigation of international currents of architectural thought at a time the Modern Movement was being reassessed globally. ${ }^{12}$ These architects are also distinguished by positions of privilege in Pakistani society. With few local institutions for training in the 1950s, most were educated abroad. Associated with elite circuits through family connections, their fledgling practices found a ready market for private commissions. The play of ideas that has characterised Mumtaz's professional path cannot be seen outside of this context: his ability to dwell on the problem of 'dwelling' has been enabled by his distance from the economic pressures, land disputes, and the discourse of 'need' that informed large-scale development projects elsewhere in the country, even if he initially desired to have an impact in such domains, for instance through an early interest in mass housing. ${ }^{13}$

\footnotetext{
12 Extant histories of architecture in Pakistan are piecemeal, compiled by enthusiasts or architects themselves and reflecting on individual cities or careers, rather than forging a sustained, disciplinary conversation about context, concepts, style and approaches. An example of the constrained, if eminently readable, nature of this literature is Zahir-ud Deen Khwaja's Memoirs of an Architect (Lahore, 1998).

${ }^{13}$ I am grateful to an anonymous reviewer for encouraging this reflection.
} 
While acknowledging that architects like Mumtaz - or Yasmeen Lari, Habib Fida Ali, Nayyar Ali Dada, Arif Hasan or others of this generation - are not representative of the majority of building design in Pakistan, my broader research project maintains that their approaches to building and ways of thinking about buildings constitute distinct responses to vital questions in Pakistani history and politics, whether these be the nature of shelter, the constitution of a 'public', the meaning of time, the organisation of labour, and beyond. This, then, is not a project about how architecture becomes a terrain to consolidate national identity in Pakistan; it is drawn instead to building work that opens space for reassessment and dispute. I am interested less in monumental or iconic projects than in unusual, marginal and even unfinished buildings, precisely for the contests and obstacles they make clear. ${ }^{14}$

The present article draws together archival research, interviews and ethnographic reflection to construct an intellectual biography of Mumtaz. Section II provides background on Mumtaz and his training as a professional architect. Section III explores how his approach to the problem of 'dwelling' is informed by attempts to author a comprehensive history of architecture in Pakistan. Section IV moves to the labour of 'building', focusing on Mumtaz's resuscitation of the 'master builder' and an ethics of craft in his attempt to reorient the aims of architecture in Pakistan's present. The theme of Section V is 'dying', orientated around one important building: a mausoleum designed for two Sufi saints in

\footnotetext{
14 Two recent books informing my approach do, however, take the monumental and iconic as central: Mrinalini Rajagopalan, Building Histories: The Archival and Affective Lives of Five
} Monuments in Modern Delhi (Chicago, 2016); and Michal Murawski, The Palace Complex: A Stalinist Skyscraper, Capitalist Warsaw, and a City Transfixed (Bloomington, IN, 2019). 
Lahore. Still under construction after nearly twenty years, this structure provides a space to explore Mumtaz's trajectory but also to ground the Heideggerian thematic alluded to in this article's title: the notion that a building is not automatically a 'dwelling' and that 'to dwell' requires a certain sort of relationship to being, a gathering of the divine in built form. ${ }^{15}$ This is a position debated in architectural practice since it was articulated in the 1950s but which Mumtaz takes very seriously indeed. The slow, sustained process of building the mausoleum demonstrates Mumtaz's commitment to a 'recursive' understanding of time, which he places against the 'generative' temporalities of modern architecture and the compulsion towards originality therein. ${ }^{16}$ Considering the implications of this perspective for architectural thought and practice, I conclude with some reflections on construction, conservation and development in twentyfirst century Pakistan.

\section{London, Kumasi, Lahore}

Mumtaz was born in British India in 1939; his father was a civil engineer, his mother an artist. He completed his A-levels at the elite Lahore boarding school

\footnotetext{
${ }^{15}$ Heidegger, 'Building Dwelling Thinking'. Based on a 1951 lecture given in Darmstadt, Germany, the essay became an important reference for architects seeking to ground their work in context, against the alleged tabula rasa reductivism of the Modern Movement. I return to the reception of Heidegger later in this essay.

16 I borrow this contrast between 'recursive' and 'generative' temporalities from Uri Gordon, 'Prefigurative Politics between Ethical Practice and Absent Promise', Political Studies 66:2 (2017), 521-37.
} 
Aitchison College before travelling to London in 1957 where he would train at the prestigious Architectural Association (AA) School of Architecture. Here, Mumtaz would be absorbed by his training but also the excitement of student politics and metropolitan art worlds: an accomplished painter, his work was exhibited in London, Cardiff, Oxford and Edinburgh. ${ }^{17}$ Following the completion of a term of work with the architectural office of Messrs Quine and Newberry in London, Mumtaz received his accreditation from the Royal Institute of British Architects in 1963. By this time he had also completed a postgraduate course in the AA's Department of Tropical Architecture, a pathbreaking programme overseen by Otto Koenigsberger, a major voice in modern urban development and famous for his work on 'climatic architecture'. Trained in Berlin and Cairo, Koenigsberger had worked in India as chief architect and planner to the state of Mysore from 1939 and Director of Housing for the new government of India in 1948. In 1953, he was appointed to the AA and in a new specialist department taught Mumtaz and a whole generation of architects from the global south. ${ }^{18}$ London at this time has been described as the "capital of tropical architecture knowledge" - with that word 'tropical' operating as a politically appropriate substitute for 'colonial' in an age of decolonisation, even as it continued to manifest a concern for uplift and progress in its desire to facilitate 'development'. The name also signalled the importance of climatological

\footnotetext{
17 Mumtaz's 1966 CV, in National College of Art (hereafter NCA) Archives 279 F: (P/File H-35). 18 Patrick Wakely, 'Otto Koenigsberger Obituary', The Guardian, 26 January 1999. Koenigsberger's papers are stored at the Architectural Association Archives in London. An article in the AA Journal (April 1963) notes that Mumtaz was joined in his cohort by architects from India, Indonesia, Iraq, Kenya, Singapore, Trinidad and elsewhere.
} 
principles in its technical and theoretical approach. ${ }^{19}$ Tropical architecture emphasised regional particularity and the necessity of refining the technological and formal advances of modern architecture to a diversity of contexts, materials and weather conditions. The AA curriculum included such topics as 'earth' as building material, air movement and 'shadow construction', disease prevention, the economics of developing countries, and 'traditional group patterns'. ${ }^{20}$ The programme did not simply assemble architects from "tropical countries" in the metropolis but also sent its teachers and former students out into the world. ${ }^{21}$ In 1964, Mumtaz was recruited to join an AA delegation, led by Michael Lloyd, tasked with reviving the School of Architecture, Planning and Building in the Kwame Nkrumah University of Science and Technology, Kumasi, Ghana. ${ }^{22}$ Mumtaz leapt at the chance and accepted a contract as Lecturer and Studio Master.

Lloyd, a colleague of Koenigsberger's and later Principal of the AA, recalls his time in Kumasi as forcing him to confront the "tragicomic" irrelevance of standard British architectural curricula in the African context but also the paternalistic, colonial relationships he saw as preserved in the act of teaching. ${ }^{23}$ Adaptations were made swiftly. The traditional course on architectural history -

\footnotetext{
${ }^{19}$ Natalia Solano-Meza, “Against a Pedagogical Colonization”, Charrette 4:2 (2017), 47; Hannah le Roux, "The Networks of Tropical Architecture", Journal of Architecture 8 (2003), 337-54.

20 Department of Tropical Architecture 1957 lecture programme and 1965 programme handbook (72:37 [42] ARC), AA Archives.

211965 programme handbook, 29 (72:37 [42] ARC), AA Archives.

${ }^{22}$ Michael Lloyd, 'Design Education in the Third World', Habitat International 7:5/6 (1983), 367.

${ }^{23}$ Lloyd, 'Design Education in the Third World', 368; Solano-Meza, 'Against...'.
} 
moving from "Egypt through Greece to Bauhaus" - was replaced with a course on the comparative study of world culture and special studies of Africa, which Mumtaz helped to convene. ${ }^{24}$ But for the most part, the emphasis was on developing technical skills and 'scientific' approaches, refined in collaborative projects with Ghana's Department of Social Welfare and Community Development. Mumtaz along with his AA contemporary Patrick Wakely completed studies for rural resettlement projects and a schools building programme. They worked alongside visiting lecturers like Jane Drew (who wrote the influential 1956 manual Tropical Architecture in the Humid Zones with Maxwell Fry), the American architect Buckminster Fuller and the historian and artist Keith Critchlow, with Kumasi emerging as a vibrant space of experimentation in its search for an architecture 'appropriate' for this part of Africa. $^{25}$

In 1966, after two years in Kumasi, Mumtaz returned to Pakistan to take up a position as head of the Department of Architecture at the National College of Arts (NCA) in Lahore. Established in 1875 by Lockwood Kipling as the 'Mayo School of Industrial Arts', the institution was hollowed by partition but revived as the NCA in 1958, with the American art historian Mark Ritter Sponenburgh serving as Principal until 1961. Sponenburgh's energies were supported by the West Pakistan Government, which had "come to realize that the country is in

\footnotetext{
${ }^{24}$ Lloyd, 'Intentions', Arena: the Architectural Association Journal 82: 94 (1966) [Special Number on Kumasi], 40, 56.

${ }^{25}$ Mumtaz reflects on this moment in his Modernity and Tradition: Contemporary Architecture in Pakistan (Karachi, 1999), 41.
} 
great need of well trained artists, architect and designers." 26 Sponenburgh was not the only American on staff: funding from the United States Educational Foundation and Fulbright Programme supported visiting Professorships throughout the early 1960s. Mumtaz would be the first Pakistani to head the Department of Architecture, and would do so from 1966 to 1975. He arrived in Lahore with strong support - his mother was a family friend of the artist Shakir Ali, Sponenburgh's successor as Principal, and his application included a reference from celebrated Pakistani poet and leftist activist Faiz Ahmed Faiz. ${ }^{27}$ Mumtaz's experiences in London and Kumasi aligned well with Ali's vision for the School - the nuanced application of modern methods of building and design, attuned to regional particularity and the challenges of a 'developing' context. ${ }^{28}$ This was Field Marshal Ayub Khan's Pakistan, and the project of development had acquired hegemonic status in state discourse - even if, as Markus Daechsel has shown, its institutions, policies and images were deployed to shore up the sovereign status of the military leader as much as to alleviate suffering or inequality in Pakistani society. ${ }^{29}$

As head of Department at one of Pakistan's most prestigious educational institutions, the young Mumtaz was given an enviable platform to reframe

\footnotetext{
${ }^{26}$ NCA Archives 259 E: Scheme for the Development of Architectural Department, 1960-61.

${ }^{27}$ NCA Archives 279 F: (P/File H-35). On Mumtaz's family entanglements with early Pakistani communism, see Kamran Asdar Ali, Surkh Salam (Karachi, 2015), 70-76.

28 This is evident in Lloyd's reference for Mumtaz, dated 9 Sept 1966 in NCA Archives 279 F:

(P/File H-35).

${ }^{29}$ Markus Daechsel, Islamabad and the Politics of International Development (Cambridge, 2015), 167, 260.
} 
architectural education in the country, injecting the rigorous contextualism he had learned from Koenigsberger and others into the NCA curriculum. He also continued to experiment with building, establishing the private practice BKM Associates with the America-trained architect Fuad Ali Butt - who had been oneyear Mumtaz's junior at Aitchison - and the engineer Hashim Khan. Early projects include schemes for low-cost housing and the design of structures easily constructed with traditional methods for peasants and farmers, notably the 1969 Kot Karamat project. Kot Karamat demonstrated how tropical architecture's technocratic assumptions might run up against local resistance. The project utilised local materials and self-help methods, but was still pursued with what Mumtaz later described as a 'scientific logic' and a framework of efficiency. Most damningly, it was imposed on the community from above: Mumtaz's arches and vaulted roofs, which he rationalised as forms appropriate to brick and lime mortar, were rejected by the inhabitants. A flat roof, they argued, would have allowed for more usable space, for instance to dry crops or to sleep outside in hot weather. ${ }^{30}$

Mumtaz would continue to revise his assumptions and approaches throughout the 1970s, becoming increasingly critical of how imported notions of building and design were being upheld as the path to 'progress', welcomed by his

\footnotetext{
${ }^{30}$ Arches and vaulted roofs were familiar locally, but associated with wealthier or ceremonial buildings rather than simple farm dwellings. Zarminae Ansari, “A Contemporary Architectural Quest and Synthesis: Kamil Khan Mumtaz in Pakistan" (Unpublished MSc Thesis, Massachusetts Institute of Technology, 1997), 48-9, 57. A parallel case may be seen in local critiques of Hassan Fathy's famous New Gourna project in Egypt. See Panayiota Pyla. “The Many Lives of New Gourna," Journal of Architecture 14:6 (2009): 715-30
} 
students and by public and private clients alike, while local preferences and practices of construction were branded 'backward' or inefficient. The context for this reassessment was a Pakistani political scene animated by the left populism of Zulfikar Ali Bhutto, whose tenure as President and then Prime Minister (197177) followed the overthrow of Ayub Khan's martial rule in 1969 and was propelled by a rhetoric of anti-imperialism, third world solidarity and Islamic socialism, even if ultimately the government fell far short of its radical promise. ${ }^{31}$ In this fertile political moment, even tropical architecture, calibrated to detect difference and responsive to a multiplicity of voices, would fall short reproducing, for Mumtaz, a model of knowledge transfer that privileged Western centres. Foreign experts like Doxiadis might advocate sensitivity to context and consultation with those affected by development plans, but for Mumtaz the issue was more fundamental: even if these authorities try to listen, there is only so much they are able to hear. ${ }^{32}$ Architecture in the modern world is grounded in certain presumptions, certain ways of thinking. Instead of simply adapting modern innovations to a 'developing' context or to the particularity of climate, Mumtaz began to think about a project of recovery, of restoring dignity to that which had been lost to the enormous condescension of professional architecture - traditional ways of thinking space and structure, embodied most powerfully in the figure of the master craftsman. ${ }^{33}$

\footnotetext{
${ }^{31}$ Akhtar, Politics of Common Sense; and Sadia Toor, The State of Islam (London, 2011).

${ }^{32}$ Daechsel, Islamabad..., 46-7.

33 I deploy 'craftsman' with full awareness of its gendered occlusions. In maintaining Mumtaz's usage of the term, I mean to underline a certain imaginary of traditional building practice and its proper subject in contemporary Pakistan.
} 
The celebration of artisan labour against the corruptions of industrial modernity has a long history in South Asia, as Saloni Mathur has shown. The craftsman became a nationalist cult figure in the late $19^{\text {th }}$ century, informing 20th century mobilisations from swadeshi to Gandhi's spinning wheel, even though its symbolic currency was constituted in part by the documentary efforts of colonial ethnologists and entrepreneurial orientalists, the latter profiting from European markets for Indian design. ${ }^{34}$ Based at the NCA, it is perhaps unsurprising that Mumtaz would be drawn to craftwork: though the institution had been restructured in the 1950s, it still derived a sense of identity and prestige from its predecessor, the Mayo School, which Kipling had pursued in part to preserve artisan traditions from the more deleterious effects of British rule. ${ }^{35}$

But in his writing and interviews, Mumtaz attributes his turn to craft vernaculars to two factors: first, his experience of leftist political activism in the 1970s, where his work with peasant movements as an artist and poster-maker forced him to think more seriously about vernacular culture and popular communication; and second, his encounter with Nader Ardalan and Laleh Bakhtiar's 1974 book, The Sense of Unity: The Sufi Tradition in Persian Architecture. ${ }^{36}$

\footnotetext{
${ }^{34}$ Saloni Mathur, India by Design (Berkeley, 2007), especially Chapter 1. See also Abigail McGowan, Crafting the Nation in Colonial India (New York, 2009)

35 Mathur, with a nod to James Clifford, describes this as the British Empire's 'salvage paradigm': India by Design, 32.

${ }^{36}$ Interview with Kamil Khan Mumtaz, Lahore, 12 February 2018.
} 
For the architect Ardalan and Islamic scholar Bakhtiar, writing in the context of Pahlavi-era Iran, architecture must go beyond the mere sensitive deployment of local materials and technologies but also channel the spirit and culture of a people. In Iran - and so too for Mumtaz in Pakistan - 'traditional' architecture was upheld for demonstrating the rich connection not simply between 'man' and his 'buildings', but also a third constitutive node, that of the divine, of the cosmos that structure any creation. Drawing on the esoteric principles of Sufi thought, Ardalan and Bakhtiar argue that Islamic architecture in Persia is characterised by its reflection of a transcendent source, of the presence of God in man's activities, an aspect of culture denied by imported Western styles and methods. Mumtaz describes Ardalan and Bakhtiar's book as 'converting' him to the pursuit of an architecture that attends to the "divine unity" underlying the "apparent physical reality of discrete phenomenon". ${ }^{37}$ I will discuss below this specific approach to building and design, but important to note here is that the connection forged between spiritual inspiration and the labour of making enables Mumtaz's turn towards a 'recursive' temporality, one that is invested in processes of repetition and recurrence, and which stands in stark contrast to the 'generative' time underlying modern architecture and its pursuit of creative innovation, or indeed the novel contextual adaptations that begin to take place in this same period under the name 'postmodernism'. As the 1970s unfolds, Mumtaz is drawn to affirm a conservative premise for building, the need for stability and legibility in a given context, in contrast to the disruptive necessity articulated by those architects

37 Mumtaz, Modernity and Tradition, 42, 30. 
who see the built environment as forging new paths for the future and crafting new ways of living.

Critics have noted that Ardalan and Bakhtiar's project of 'tradition' was facilitated by the populism of the Pahlavi regime and its attempts to co-opt those Iranians left out of the modernization process. Indeed, Ardalan fled Iran for exile following the 1979 Revolution. His attachment to Sufi principles can be read as an attempt to proffer an alternative vision of Islam against Khomeini's theocracy. ${ }^{38}$ Ardalan's collaboration with Bakhtiar, for historian Kathleen JohnAlder, reflects the personal struggles of an Iranian architect raised and trained in the United States navigating his place within the region and amidst a global architectural community. ${ }^{39}$ But these features - a privileged upbringing and foreign training, a context of populist politics, a preference for an esoteric understanding of Islam against increasingly prominent orthodox visions resonate too with Mumtaz, and the complexity and consequences of the Lahori architect's position are explored below.

III. Building and Thinking in Mumtaz's History of Architecture

\footnotetext{
38 This, indeed, was the project of Ardalan and Bakhtiar's mentor, Seyyed Hossein Nasr, who provided a foreword to The Sense of Unity: The Sufi Tradition in Persian Architecture (Chicago, 1973). See also his Traditional Islam in the Modern World (London, 1987).

39 Talinn Grigor, Building Iran (New York, 2009), 164-5; and Kathleen John-Alder, "Paradise Reconsidered" in Mohammad Gharipour, ed., Contemporary Urban Landscapes of the Middle East (Abingdon, 2016), 120-148, 137.
} 
Professional architecture in the decades after the Second World War began to grapple with what architectural historian Kenneth Frampton has called "the implosion of utopia upon itself." 40 Mumtaz was not alone among his generation of Pakistani architects in criticising the failed promises of modernization, or the way in which early modernist aspirations for an 'architecture for the people' had been appropriated and commodified to service the tastes of the wealthy and the powerful. Major contemporaries like Yasmeen Lari and Nayyar Ali Dada have reflected similarly on their attempts to 'unlearn' what had once seemed the only option, though neither has gone as far as Mumtaz in rethinking the method and ethic of building in accordance with an explicitly Islamic cosmology.

Mumtaz places his reconfigured practice in a broader South Asian context, noting a common cause with architects who refused to be "bound by the limitation of any 'style"” but rather sought an architecture "appropriate to our own regions, our climate and our materials". He notes figures like Minnette de Silva and Locana Gunaratna in Sri Lanka or Ruslan Khalid in Malaysia. ${ }^{41}$ This group is internally differentiated: if architects like Geoffrey Bawa, the Colombobased tropical modernist, were more concerned with "the formal aspects of space, construction materials and building elements", others like Balkrishna Doshi and Charles Correa in India, and Mumtaz himself in Pakistan, were working to excavate "the deeper cultural significance in traditional design theories and building practices". Here, "religion and the craft sensibility",

\footnotetext{
${ }^{40}$ Kenneth Frampton, Modern Architecture, Third Edition (London, 1992), 280.

${ }^{41}$ Mumtaz, Modernity and Tradition, 34.
} 
privileged vectors to the 'local', would play a major role in shaping new architecture. $^{42}$

The playfulness and irony that characterised a turn to 'vernacular' forms and styles in European and North American postmodern architecture is not evident here; rather, there is a gravity and seriousness in the concern for the 'authentic'. The shift reflects the specific cognitive-political space of 'postcoloniality': the desire to critique European structures of knowledge and representation, and to recover and assert histories of local agency and resistance against a story of imperial domination. David Scott posits that postcolonial thought, though displacing 'anticoloniality', incorporated and took for granted the accomplishments of the latter: that is, its lines of inquiry were possible only because "the problem of the horizon of politics (i.e., nation-state sovereignty) had appeared resolved."43 Political questions could thus be deferred, even if the secular premises of the modern state and its organisational forms were being challenged. Postcoloniality's critique of Eurocentric modernity, situated within the container of the 'national', might then manifest concerns with the 'organic', the 'spiritual' and the 'traditional'. 44

In Pakistan, the conflicts this produced for a transformational politics can be seen in the career of Urdu literary critic Muhammad Hasan Askari (19191978). As a young writer, Askari was associated with the Progressive Writers' Movement but later became a vocal critic of the left in Pakistan, suggesting in the decades after Partition that communists were alienated from local culture and

\footnotetext{
42 Ibid, 80-81.

${ }^{43}$ David Scott, Refashioning Futures (Princeton, 1999), 14.

${ }^{44}$ See also Partha Chatterjee, The Nation and Its Fragments (Princeton, 1993).
} 
tradition and as such could not contribute to the national project of a properly 'Pakistani' literature. In the 1970s, Askari became increasingly drawn to Muslim history and Islamic tradition, inspired by Deobandi scholars like Ashraf Ali Thanawi but also the perennialist thought of figures like René Guénon. ${ }^{45}$ Askari even authored a short treatise on modernism, Jadidiyat, designed to familiarise madrasa students with its main premises so that they might better challenge its influence in the Islamic world. ${ }^{46}$

A departure from leftist associations, an interest in perennialist philosophy and a deferral of politics as pursuit of 'the new' structures Mumtaz's engagement with the built environment in Pakistan, as I will note below. But the architect's relationship with the state is hardly straightforward: indeed, the 1970s were a tumultuous period for the country, and Mumtaz was forced to take extended leave from the NCA in July 1977, the same month that military leader General Zia-ul-Haq overthrew Zulfikar Ali Bhutto in a coup. In 1980, he resigned

\footnotetext{
45 The 'Perennialist' or 'Traditionalist' school of thought, founded by the French philosopher René Guénon (1886-1951), articulated a critique of the modern world based on an idea of primordial, 'inner' truths shared by world religions and captured vividly in traditional forms of knowledge. Along with Guénon, the work of Ananda Coomaraswamy (1877-1947) - whom Mumtaz cites as an important influence - and Frithjof Schuon (1907-1998) helped consolidate a philosophy that challenged scientific and secular knowledge with notions of eternal wisdom. ${ }^{46}$ MH Askari, Jadidiyat (Rawalpindi, 1979). For context, see Muhammad Qasim Zaman, Islam in Pakistan (Princeton, 2019), 80-82 and Ali, Surkh Salam, 147-49.
} 
formally from the institution - pushed out, as he expressed to me with a smile in a 2018 interview, on charges of "corrupting the youth". ${ }^{47}$

Mumtaz's turn to Islamic architecture was in part a response to statelevel engagements with religion - whether Bhutto's Islamic socialism or Zia's policy of 'Islamization', which directed state patronage to the 'ulama and led to new laws against blasphemy, the establishment of shariat courts, revised school curricula, censorship measures and many more everyday reforms, from requiring prayer spaces in offices to better facilities for hajj. Rather than critiquing this growing entanglement of state and religion, it was the way Islam was stitched seamlessly to projects of development and modernization that drew Mumtaz's ire, obliterating in his view the potential for Islam to illuminate other ways of being within, or in contest with, modernity. This flawed condition was reflected in architectural practice: the fashion for the clean lines, glass and concrete of developmental modernism common in Pakistan in the 1950s and 60s was replaced from the 1970s with what Mumtaz and others have labelled pejoratively as 'Instant Islamic', characterised by the ornamental inserting of domes and arches into a built environment otherwise constructed in a Western style. ${ }^{48}$

\footnotetext{
${ }^{47}$ Interview with Mumtaz, Lahore, 12 February 2018; NCA Archives 279 F: Personal File of Kamil Khan Mumtaz, 1966-80 (P/File H-35 [250]). His specific reason for leaving is not given but there is repeated mention of Mumtaz's involvement in "disturbances".

${ }^{48}$ See, for instance, Yasmeen Lari's 'Preface' to Traditional Architecture of Thatta (Karachi, 1989). As one reviewer of this essay observed, the transformation of religious ornament into massproduced market commodity ironically fulfils Mumtaz's call for a 'lack of originality' in design albeit without the ethic of building and dwelling he is prescribing.
} 
How to refute these impatient, top-down exhortations with a more nuanced engagement with Islam and its meanings in Pakistan? For Mumtaz, like Ardalan and Bakhtiar, architects must attend to history. His engagement with the past would not be some nostalgic lament for things lost - a romanticization of ruins - but a concerted attempt to recover tactics, practices and methods of building that for centuries flourished in the territories now called Pakistan but which find no place in any technical education programme or professional architectural degree. For Mumtaz, these are not lost but "living" traditions and can be activated as 'strategies' for the present. Speaking to the Asian Congress of Architects in Lahore, October 1992, he impressed that, "we can continue to ignore or deliberately misrepresent the past only at the risk of formulating arbitrary, and faulty strategies, or moving into the future without any strategy at all. In the absence of a sound theory based on the collective experience of our own past and our own present, our architecture can only be arbitrary and irrelevant at best and downright dangerous at worst." 49

A search for 'origins' and an interest in 'authentic' methods animates Mumtaz's 1985 study, Architecture in Pakistan, still the only national survey of building practices that has been written. ${ }^{50}$ The book was published under the Singapore-based Mimar imprint, best known for its international 'Architecture in Development' magazine of the same name and supported by the Aga Khan Trust for Culture. ${ }^{51}$ It builds on work Mumtaz had done in the 1970s for the UNESCO Division of Cultural Development, which had commissioned studies on "the most

\footnotetext{
${ }^{49}$ Mumtaz, Modernity and Tradition, 48.

${ }^{50}$ Kamil Khan Mumtaz, Architecture in Pakistan (Singapore: Mimar, 1985).

51 The digitized Mimar catalogue is available via ArchNet: https://archnet.org/collections/56.
} 
important forms of traditional architecture in Pakistan." 52 We are reminded here of the global dynamics that can inform a concern for the local and the regional, and indeed this is demonstrably true of Mumtaz's experience.

Architecture in Pakistan demonstrates Mumtaz's efforts to establish a sense of chronology in defiance of colonial and modernist ruptures. The book travels across the length and breadth of Pakistan to provide a comprehensive overview of "building activities" within its territorial borders, from earliest evidence to the contemporary moment. Mumtaz the historian is strongest in discussing more recent periods, but the text ventures as far back as $3200 \mathrm{BC}$, drawing on archaeological research into the Kile Gul Mohammad site near Quetta city and the pre-Harappan cultures of the Indus Valley. Written over a decade after the independence of Bangladesh, Mumtaz is only interested in what he calls the 'new Pakistan' of the four provinces - Sindh, Baluchistan, Punjab and what was then called the North-West Frontier Province - and doesn't discuss the significance or influence of building activities in the former East Pakistan at any point. ${ }^{53}$ Demonstrating the normative power of the nation-state at this historical moment, Mumtaz projects the bordered territory of (West) Pakistan back into time - so that the Buddhist culture of Gandhara developed out of the "fusion of

\footnotetext{
52 See correspondence between UNESCO's W Tochtermann and Mumtaz, June 1975, in NCA Archives 279 F: (P/File H-35). Tochtermann introduced the project as part of an endeavour to “collect information on Asian 'architecture without architects'.”

53 When, in a 2018 interview, I asked Mumtaz about the absence of Bangladesh, he countered that there was indeed a long-standing conversation in terms of methods and approaches, particularly with Muzharul Islam, a leading voice in "regional modernism" debates who also trained at the AA in the 1950s.
} 
Greek, Central Asian, Indian and Pakistani cultures"; or noting that, "by the $7^{\text {th }}$ century, Hindu revivalism had virtually eliminated Buddhism from the subcontinent, and Pakistan was once again a satellite of India." 54

This lack of reflexivity over the category of 'Pakistan' means Mumtaz's text is consistent with forms of official imagining in the country, where attempts to nationalize the past have relied on what Ayesha Jalal has called "an improbable array of conjuring tricks, and some somersaults on the tightrope of historical memory." 55 The original study was commissioned by the civil servant Altaf Gauhar, Information Secretary under Ayub Khan and later editor of major Pakistani daily Dawn, indicating Mumtaz anticipated a national audience alongside the international readership enabled by Mimar and the Aga Khan Trust. ${ }^{56}$ More generously, it could be said that Mumtaz endeavours to breathe heterogeneity into this category, 'Pakistan', since what emerges in this book is not a singular trajectory but a proliferation of forms and approaches, which vary by region, climate and material even if they are all gathered under one national descriptor. For Mumtaz, "the wooden mosques of the northern region are as much a part of Pakistan's traditional architecture as the Gopa huts of Cholistan or the wattle-and-daub town houses of Thatta". ${ }^{57}$ Yet the primary lesson Mumtaz

\footnotetext{
${ }^{54}$ Mumtaz, Architecture in Pakistan, 4.

${ }^{55}$ Ayesha Jalal, “Conjuring Pakistan: History as Official Imagining”, International Journal of Middle East Studies 27 (1995), 73-89, 74.

56 Interview with Mumtaz, Lahore, 12 February 2018; Mumtaz, Architecture in Pakistan, 2. The choice of English as language of communication privileges the latter but also reflects the lingua franca of professional architectural practice in Pakistan.

${ }^{57}$ Mumtaz, Modernity and Tradition, 57.
} 
derives from this research is not one of diversity within a national container but rather an ethic of craft that can be seen to bind highly variant structures. His vision for architecture in Pakistan is not centred on a particular form, material or technology but rather a specific approach to building: that demonstrated by the traditional or master craftsman, a figure who suffuses the process of construction with a piety derived from Islam, and who, in their temporal disposition and engaged approach to making, disrupts the authority accorded to the architect and the alienating nature of building work in the modern age.

Mumtaz's fundamental critique of modern architecture is articulated in these terms: against the elevation of the architect and their relentless pursuit of novelty or originality, and for the recovery of the modest craftsman, the traditional builder - the discarded master. His intervention is not primarily one of space (i.e. context, locality and what is 'appropriate') but rather one of time, a critique of what he sees as the architect's egotistic pursuit of the future, their obsession with innovation, and their denial of what they have inherited, the slow, repetitive rhythm that might attach them to the past. Over subsequent decades, Mumtaz has worked to recalibrate his practice in line with an ethic of craftwork and its recursive temporalities, even if bridging the gap between that ideal craftsman-hero and the lived reality of building has not been a straightforward one. It is to that displaced figure of authority that I now turn.

\section{The Discarded Master}

A lament for the discarded master builder recurs throughout Mumtaz's writings, interviews and public addresses. The blame for this figure's peripheral status is 
placed squarely on the transformations of modernity - the changes in building technology it brought and the secular vision of progress it instilled in the mind of the architect, a profession that became increasingly removed from the contexts of construction and the collective expertise of the workshop or guild. The craftsman's way of thinking about and working with the built environment was not, for Mumtaz, destroyed by colonial interventions nor by the post-colonial ascendancy of developmental modernism, but rather marginalised, sustained in an impoverished state by "our hereditary craftsmen."58 Mumtaz participates in a larger critique of the social and psychological alienation caused by the mechanization of labour, one that stretches from Karl Marx's writings on nineteenth century industrial capitalism to Richard Sennett's recent celebration of expressive and meaningful work against twenty-first century neoliberalism. ${ }^{59}$ But his prescription is less one of revolution than of restoration. In the South Asian context, Mumtaz echoes Ananda Coomaraswamy's early twentieth-century appeal to acknowledge the physical as well as spiritual superiority of the artisan to the industrial factory worker; "it is these skilled craftsmen...whom we as a nation most need as members of our body politic". ${ }^{60}$

\footnotetext{
${ }^{58}$ Mumtaz, Modernity and Tradition, 38. For variations on this theme in the history of Muslim societies, see Peter Christensen, ed., Expertise and Architecture in the Modern Islamic World (Bristol, 2018).

${ }^{59}$ On this genre of thinking see Thomas Yarrow and Siân Jones, “'Stone is Stone”: Engagement and Detachment in the Craft of Conservation Masonry', Journal of the Royal Anthropological Institute 20 (2014), 257; Richard Sennett, The Craftsman (New Haven, 2008).

${ }^{60}$ Ananda Coomaraswamy, Art and Swadeshi (Madras, nd [ 1912]), 22; Mathur, India by Design, $44-46,49$
} 
In the humility and modest scale of the "vernacular craft tradition"

Mumtaz locates a model for building practice that might disrupt a modern notion of progress, its "obsession with the creative artists, whose highest ambition is to be acclaimed and applauded as a high priest of the deity of innovation."61 Traditional architecture is concerned primarily with

function, space, light, protection against the elements and structural stability, available materials, construction techniques etc. [...] In all of these crafts and arts the criterion of quality is never creativity, in the sense of originality or innovation, but the degree to which the product conforms to pre-existing conventional forms. ${ }^{62}$

This conscious embrace of derivation, the pursuit of continuity through repetition, is in part a rejection of modernity's 'cult of inventiveness', but it is also justified as true to Pakistan's "traditional Islamic context”, in which it would be considered "presumptuous of any individual to claim for himself a role [i.e. as a 'creator'] which was the exclusive prerogative of God." The craftsman, in Mumtaz's account, aspires only “to reflect or faithfully represent an 'ideal' which already existed in the world of archetypes."63

Mumtaz departs from those celebrations of craftwork familiar in a European context, from John Ruskin to William Morris, with their dimension of anti-capitalist critique and promise of labour without submission or servility. His clearest influence is instead Ardalan and Bakhtiar, who in The Sense of Unity identify a programme for building and working which guarantees "the spiritual validity of forms". ${ }^{64}$ Exploring Persian architectural history, Ardalan and

\footnotetext{
${ }^{61}$ Mumtaz, Modernity and Tradition, 17.

62 Ibid, caption to Plate 8.

63 Ibid, 63.

${ }^{64}$ Ardalan and Bakhtiar, Sense of Unity, 10.
} 
Bakhtiar emphasise the importance of craft guilds as sites of knowledge. Each is directed by a master "who is both a Sufi and a craftsman who possesses a conscious knowledge of the principles governing his art"; their works are "like arts of nature, at once functional, cosmic and imbued with a nobility of expression that seeks the Truth through the Way."65 Mumtaz notes that craftsmen in the territory that is now Pakistan have historically been inducted into a Sufi silsala (spiritual lineage) as prerequisite to their building practice, connecting them to a form of sacred authority. ${ }^{66}$ In Ardalan and Bakhtiar's reckoning, the spiritual hermeneutics or taw'il guiding this work operate on an alternative model of time: "Events are not important as linear developments; rather, through them, one seeks an orientation towards a vertical axis uniting earth with the heavens." 67 Building practice relies on deference to God, rather than the hubristic positioning of the builder as God.

The space of the craft guild or workshop offers insights into the ethics of craftwork and the relationships forged in its midst. The workshop is a site of collective agency, of collaboration and interdependence, but remains structured by hierarchical authority. This authority, that of the 'master', is determined by skill, commitment, and a form of judgment that is technical and, for Mumtaz, also spiritual. ${ }^{68}$ The workshop is held together by ideas of honour, the dignity of obedience and legitimacy established by actions "in the flesh, not in rights or

\footnotetext{
65 Ibid, 5.

${ }^{66}$ Mumtaz, Modernity \& Tradition, 66-7.

${ }^{67}$ Ardalan and Bakhtiar, Sense of Unity, 5.

${ }^{68}$ On the institution of the workshop across a diversity of contexts, see Sennett, The Craftsman.
} 
duties set down on paper."69 Mumtaz's evocation of committed labour in contemporary Pakistan transmits a polemic, especially with regard to this latter point. Against the proliferation of 'specialists' - consider Daechsel's work on the revolving door of development 'experts' and foreign consultants characterising Pakistan's post-colonial decades - Mumtaz positions the dignified pursuits of the grounded 'comprehensivist'. ${ }^{70}$ The discarded master represents a morality and modality of authority which Mumtaz sees as rare and undervalued in Pakistan today - one characterised by discipline, humility, and a passion for work qua work, approaching labour as an end in itself, something to be done with care and with no eye to reward or desire for praise. This vision of craftwork is gendered and generational in its focus on the presumed physical capacities of male bodies and its valorisation of accumulated experience. And yet the disposition it promotes in relation to time and the nature of action is portable: the primacy accorded to engagement can be mobilised as a broader critique of alienation in Pakistan's political present. ${ }^{71}$ An ethic of craft might, for instance, be extended to something like citizenship, the manner in which one understands their responsibilities to society..$^{72}$

\footnotetext{
${ }^{69}$ Sennett, The Craftsman, 54; see also the emphasis on 'unity and equality' among Scottish masons, alongside a clear hierarchy in terms of experience, temperament and character in Yarrow and Jones, "'Stone is Stone"', 261.

70 Daechsel, Islamabad..., especially Chapter 2.

71 For a questioning of this primacy, see Yarrow and Jones, '"Stone is Stone"'.

72 On the portability of craft ethics, see Frederico Bellini, “Cormac McCarthy's The Stonemason and the Ethic of Craftsmanship", European Journal of American Studies 12:3 (2017), 1-14.
} 
Mumtaz's rehabilitation of 'tradition' as possibility rather than proscription is echoed by other projects across the Islamic world during this period: besides Ardalan and Bakhtiar's investigations in Iran, consider the growing interest in Hassan Fathy's experiments with 'appropriate' technology in Egypt, Muzharul Islam's desire to facilitate traditional relationships with nature in Bangladesh, or the establishment of the Aga Khan Award for Architecture in the late 1970s in part to support an architecture that might embody Islamic values. ${ }^{73}$ But in Pakistan, Mumtaz's emphasis on practice and disposition rather than form or technology appears as a response to the particularity of this country, its fragmented citizenry and diverse geography, proposing an ethic of building and cultivating that might create the conditions for harmonious dwelling.

The example of the master builder allows Mumtaz to reimagine the relationship between architecture and time, emphasising three aspects: patience, derivation and duration. The first relates to the time of building itself, which should be removed from a capitalist logic of productivity and efficiency and instead approached as a meditative practice of repetitive movement and even as a form of worship. In a recent essay on Sufi shrines, Mumtaz quotes from the account of a $16^{\text {th }}$-century Lahore builder, Ustad Bazid, the son of "an ordinary mason who worked with mud mortar" and who was involved in the construction of a mausoleum in Shergarh.

\footnotetext{
${ }^{73}$ Indeed, Fathy was the first winner of the Aga Khan Chairman's Award in 1980. See his influential Architecture for the Poor (Chicago, 1973). For insights into the function of tradition more generally in Pakistan, see Humeira Iqtidar, "Redefining 'tradition' in political thought", European Journal of Political Theory 15:4 (2016), 424-44.
} 
Before every brick that we put in place I would invoke God's blessings upon the holy Prophet, may Allah's blessings and peace be upon him. Virtuous men, devotees and seekers of the spiritual path would recite the chapter Ikhlas [Qur'an 112] twice over as they passed on each load of bricks or mortar. There were so many people and such a crowd that each turn to hand over the bricks would take rather a long while and with great difficulty. In this manner the construction of the radiant tomb was accomplished in four years. ${ }^{74}$

Mumtaz commends Bazid's patient endurance, describing the tomb as "conceived and built as an act of devotion by pious souls."75 Even discounting this spiritual dimension, the use of traditional methods inculcates a different relationship to productivity: bricklaying, in its rhythm of gradual accumulation and repetitive action, accentuates the passage of time. The demands of skill and quality in the building process encourage Mumtaz to dismiss the impatience facilitated by architectural abstraction - the clean remove of blueprints, the rapid ease of CAD software - and instead emphasise patient, hands-on engagement as virtue. ${ }^{76}$

The second lesson inverts conventional relationships to form. Mumtaz's understanding of Islamic craft traditions discourages the pursuit of originality and an idea of the new as broken from the old. The architect should thus not pursue the 'creation' of forms but rather facilitate their 'realization'. In his forward to The Sense of Unity, Iranian philosopher Seyyed Hossein Nasr notes that, "there is nothing more timely today than that truth which is timeless, than the message that comes from tradition and is relevant now because it has been

\footnotetext{
${ }^{74}$ Cited in Mumtaz, "The Architecture of Sufi Shrines” in Samina Quraeshi, Sacred Spaces (Cambridge, Mass., 2009), 42.

75 Mumtaz, "Architecture of Sufi Shrines”, 43.

${ }^{76}$ A jibe I heard on fieldwork suggested that, if one commissions Mumtaz to build a house, they shouldn't expect to move in for ten to twenty years.
} 
relevant at all times."77 Narratives of novelty are traded for an architecture whose quality and power is measured in terms of "conformity to pre-existing conventional forms".78

Repetition and reproduction become central to Mumtaz's practice. Copying as a method of design and instruction is central to the organisation of craft workshops, structuring the relationship between an apprentice and a master, but for Mumtaz this strategy had been unthinkable in his own education and training as an architect: "The compulsion to be innovative, to be creative, to be original, the imperative to be 'expressive of our time' had always stopped me short of what could be seen as imitation and copying. In the final analysis, my ego simply refused to let go, to surrender."79 It was only through the guidance of a spiritual master - the famous perennialist philosopher Abu Bakr Siraj-ed-Din, born Martin Lings - that Mumtaz claims that he has been able to cross this barrier, and I will note the results in the next section. ${ }^{80}$ An emphasis on repetition and imitation does not mean stasis: traditional craftsmen are expected to adapt their practice to the vagaries of context and the materials available, responding sensitively to their environment. The point is that changes are motivated by such specific obstacles or prompted by divine guidance, rather than by "an individual's personal vanity". 81

\footnotetext{
${ }^{77}$ Foreword by Nasr in Ardalan and Bakhtiar, Sense of Unity, xi. Bakhtiar was Nasr's student at Tehran University in the 1960s.

78 Mumtaz, Modernity and Tradition, Plate 8.

${ }^{79}$ Mumtaz, "Architecture of Sufi Shrines”, 54.

${ }^{80}$ Interview with Mumtaz, Lahore, 12 February 2018. Lings was a student of Frithjof Schuon.

${ }^{81}$ Ardalan and Bhaktiar, Sense of Unity, 10.
} 
Third and finally, the work of the discarded master allows Mumtaz to emphasise the obdurate quality of traditional architecture - its design and construction as a structure that will survive the passage of time. Returning to Ustad Bazid's sixteenth-century shrine in Shergarh, Mumtaz notes an inscription which reads, "This pure tomb of Hadrat Dawood, May God forever spread its shadow wide". ${ }^{82}$ If buildings are created through acts of devotion, and 'realize' in their form a spiritual truth - the teachings of a saint, perhaps, or a general idea of divine unity - then it follows that they should be designed to facilitate a long life, a heavy shadow. This can be ensured through the quality of building but also the respect accorded to the structures by those who dwell in them or around them. As Heidegger too reflected, to 'dwell' is also to 'cultivate', to acknowledge one's responsibility to place; otherwise a building is merely a container. ${ }^{83}$ This lesson manifests a critique of the disposability of contemporary architecture in Pakistan - the development goals or profit motives that inspire the rapid erection of structures but not their long-term maintenance - but also a plea to depart from the temptations of fashion in favour of a culturally-embedded 'timeless' quality that can endure. To assign value to qualities of duration and a building's grounded nature has other implications in Pakistan's political present, contrasting starkly with a twenty-first century reality of mobile populations, the transnational flows of migrants and the shifting affiliations of mixed and heterogeneous communities. It is perhaps unsurprising that Mumtaz has made his life in Lahore, a city noted for its palimpsestic nature, the obduracy of that which came before - and its association with a certain parochialism as a result -

\footnotetext{
${ }^{82}$ Mumtaz, "Architecture of Sufi Shrines", 43.

${ }^{83}$ Heidegger, 'Building Dwelling Thinking'.
} 
in comparison with a city like Karachi, a place shaped by migration and ongoing rhythms of erasure and renewal. ${ }^{84}$

Mumtaz describes his career as a long process of learning, and he has been able to test his ideas in the space provided by the Lahore-based Anjuman Mimaran ('Society of Architects'), a group he helped found and which for many years collected and spread knowledge about traditional building practices in Pakistan. But Mumtaz's own architectural work - his professional practice, established in his own name after a split with BKM Associates in 1984 - has faced considerable constraints, due in part to the narrowness of his clientele base. Mumtaz has a spotty record of large-scale public building work, his designs for high-profile projects like the Data Darbar shrine expansion in Lahore or the Quaid-i-Azam Memorial Mosque in Karachi rejected by juries, which Mumtaz blames variously on internal corruption, selection committees stacked with tasteless Generals, or a misguided preference for the glamour of foreign architects. As a result, most of Mumtaz's portfolio consists of work commissioned by wealthy, private clients, and much of it domestic. Indeed, the architect has benefited from a wider, elite market for 'traditional' art and culture in Pakistan, a fashion that is mirrored prominently in the popularity of 'Sufi' music and which also belongs to a historical moment, accelerating after $9 / 11$,

\footnotetext{
${ }^{84}$ I am grateful to Vazira Zamindar for encouraging me to think about this aspect of Mumtaz's biography. On Lahore as palimpsest, see William Glover, Making Lahore Modern (Minneapolis, 2008).
} 
when other ways of 'being Islamic' are salvaged by certain classes to contest rising Islamist tendencies. ${ }^{85}$

In the built form of the house, Mumtaz recounts, he has had the opportunity to explore alternative building practices, using materials, patterns and surface decoration to encourage the resident or visitor "to become aware of a reality beyond the immediate materiality of a brick wall, a marble floor, or a steel grille." ${ }^{86}$ Even this has been imperfect. Referring, for instance, to his interest in the Islamic design technique of proportional subdivision, a method used to determine the size and shape of buildings, Mumtaz notes that "such mundane obstacles as building regulations had proved, in practice, to be insurmountable." And while clients of Mumtaz's private practice are generally "supportive of our ideas", until very recently they "had not found anyone willing to realize them fully in terms of design principles, building materials, and construction techniques." 87

In the early 2000s, Mumtaz was commissioned to design and construct two different buildings, with each client encouraging him to follow his principles completely. The first building was a mosque at Pak Wigah, a pilgrimage site in the district of Mandi Bahauddin, 150 kilometres west of Lahore. His client, Dr Sahibzada Mohammed Farakh Hafeez, was an eye surgeon but also a shaikh in the Naushahi Sufi order, rooted in this area. The second building was commissioned by two engineers in Lahore, who asked Mumtaz to create a

\footnotetext{
85 For an account of this terrain, see Ammara Maqsood, The New Pakistani Middle Class (Cambridge, Mass., 2017).

${ }^{86}$ Mumtaz, Modernity and Tradition, 42-45.

${ }^{87}$ Mumtaz, "Architecture of Sufi Shrines", 54.
} 
mausoleum for their local saint, Hafiz Iqbal, and his master Baba Hassan Din in the city's Baghbanpura neighbourhood. I want to discuss this latter project in detail as a way to bring together some thoughts on building, making and time.

\section{The Tomb of Baba Hassan Din}

My exploration of Mumtaz's career as an architect has relied heavily on his words thus far, and this for two reasons: one, that professional architects are primarily engaged in processes of conceptualisation and design rather than the direct manipulation of material forms - their work involves the translation of ideas and data collected from site surveys to the page via the blueprint, the plan, the illustration; 88 and second, because much of Mumtaz's ideas about work and craft have been unrealisable in built form for the reasons discussed above. But the mosque at Pak Wigah and the mausoleum in Lahore provide the opportunity to consider the material reality organised by Mumtaz's thinking. The latter building, which I visited regularly during fieldwork periods in Lahore across 2018-19, reveals much, not least in its incomplete status, the slowness of its continuing construction. The building practice Mumtaz espouses is a minority one - in urban spaces especially and in relation to new sacred architecture generally - but its uncommon quality underlines its polemical force. This section will introduce the tomb before linking Mumtaz's processes of making to those of preserving, touching on the architect's work as a heritage activist.

\footnotetext{
${ }^{88}$ Kostof in The Architect, xvii, describes architects as "conceivers of buildings", who mediate between clients and builders.
} 
Hassan Din's tomb and shrine complex is located in the densely populated neighbourhood of Baghbanpura, east of Lahore's walled city and adjacent to Shalimar Bagh, a Mughal-era garden recognised as a UNESCO World Heritage site. It is also a short walk from Darbar Madhu Lal Hussain, the mausoleum of sixteenth century Sufi poet Shah Hussain and his companion, Madhu, the Hindu boy he is said to have loved. For centuries this has been an important anchor in Lahore's spiritual geography, remaining a site of popular devotion to this day as well as a site for subversion of norms around gender, sexuality and drug use. ${ }^{89}$ The caretaker of Hassan Din's shrine - an elderly man who has lived on the site since he was a boy and throughout the long period of construction - proudly pointed out the dome of the famous site from the front steps of Mumtaz's building on one of my visits.

Approaching the tomb on narrow streets, it is difficult to get a full perspective on the structure, though two tall minarets signal the site from afar. A hand-painted green sign announces the site to passersby, while a vault decorated with muqarnas and a cypress tree relief - a symbol of graveyards in the Muslim world - guides the visitor towards the entranceway. Started in 2001, the mausoleum is, at the time of publication, still under construction. The main structure is finished, as are decorations in the rooms that hold the saints' remains, and the building is open to devotees and other visitors. Custodians of the tomb have ample space to host an annual urs, the customary death anniversary celebrations for a Sufi saint which is intended to publicise their teachings. Certain areas remain closed off; parts await ornamentation - on the

\footnotetext{
${ }^{89}$ Amen Jaffer, 'Inhabiting the Power of the Sacred: Legitimacy and Affect in Punjabi Shrines' (PhD Dissertation, New School for Social Research, 2016).
} 
external façade, for instance, Mumtaz plans to deploy the practice of kashikari, "the unique Lahori art of glazed tile mosaics, whose last recognized master died some fifty years ago". 90 On my first visit in February 2018 I met a glass artisan who was assembling a sheesh mahal (palace of mirrors) in one area of the mausoleum. He had been working for one year and estimated it would take another four or five to finish laying the intricate patterns of small, blown glass pieces. The artisan learned sheeshakari from his father, these craft skills passed down the family line. He noted that while Mumtaz decides on the general sort of work to be done, he defers to the craftsman's expertise for details and the specificities of making.

'Appropriate' materials have been privileged, with the mausoleum built entirely of local clay bricks and bound by lime mortar prepared on site using traditional tools. Craftsmen have been commissioned for decorative schemes including stone carving, stone inlay, plaster relief (thoba and ghalibkari), fresco (naqqashi) and woodcarving, as well as calligraphy. But Mumtaz's engagement with the 'vernacular' is not so straightforward as the evolution of 'appropriate' forms from the logic of the local site. In fact the clients requested that Mumtaz use the famous shrine of Imam Ali in Najaf, Iraq, as inspiration for his design. This shrine, the holy site for Shia Muslims who regard Ali as rightful successor to Prophet Muhammad, first appeared in the $8^{\text {th }}$ century; its current form owes more to extensions and restorations pursued in the $17^{\text {th }}$ and $18^{\text {th }}$ centuries. Mumtaz agreed to adapt this model to the significantly smaller site in Baghbanpura, analysing images and plans from Najaf "to decode the underlying

\footnotetext{
90 Mumtaz, "Architecture of Sufi Shrines”, 60.
} 
proportioning systems and geometries", which were then used to establish basic structural and planning grids. ${ }^{91}$ The architect notes that, earlier in his career, such an exhortation to imitation would have been impossible to accept. But now, he explains, working from prescribed models is

never, in practice, simply a mechanical process of reproduction. It involves intelligent interpretation, adaptation, and application of critical judgment and discernment at every step of the way. As Pakistani master mason Ustad Haji Abdul Aziz would put it, 'I can give you all the formulas, the ratios, and the proportions for every element, but there always comes a point when the craftsman has to exercise his imagination. It is a question of hawa [lit. 'air'; in design the term refers to the subtleties of form]...It cannot be defined. You have to let your eye and your heart guide you.' 92

A framed image of the Najaf shrine leans against the wall in the caretaker's small room, balanced over the bed where Hafiz Iqbal himself slept for decades before his death.

Accepting Najaf as a model for 'appropriate' architecture in Lahore demonstrates how significantly ideas of the 'local' in the Islamic world have been restructured by transnational connections and sacred geographies. But such troubling of the vernacular seems justified for the domestication of Baba Hassan Din, who was in fact an Englishman born in Birmingham as Alfred Victor. Victor worked as a mechanical engineer for British Railways before being visited by the $11^{\text {th }}$ century mystic Ali Hajveri - venerated as Data Ganj Baksh, patron saint of Lahore - who exhorted him to leave his country in the 1950s. He disappeared to the forests of Kenya before settling in a small brick dwelling in Lahore's Baghbanpura, where he adopted as his disciple a poor local boy named Hafiz Iqbal, whom he educated but who continued to work as a street sweeper in the

\footnotetext{
91 Ibid, 55.

92 Ibid, 58.
} 
area. Hassan Din died in 1968, while Iqbal remained a prominent local pir (spiritual guide) until his own death in $2001 .{ }^{93}$ The caretaker explained that Hassan Din's teachings stressed modesty and humility, and were in fact critical of the authority of the maulvi (Islamic religious scholar), arguing instead that "every one of us writes their own holy book."

The built form of Hassan Din's tomb and shrine stands in stark contrast to other Sufi mazaars in the city. Though the most important of these survive in place over centuries, their structures can change dramatically. In recent years, many shrines have become increasingly ostentatious, deploying glitz and bright lights to create a spectacular effect and attract devotees, reproducing a logic of 'marketing' that pervades the management culture of shrines in an increasingly commercialised Pakistani society. ${ }^{94}$ Hassan Din's mausoleum is being constructed to provoke a different sort of mood in the visitor. But what does this insertion of a seventeenth century building into Lahore's bustling, twenty-first century metropolitan reality mean? There is undoubtedly a polemical aspect to the building - in the slowness of the work, against commercial imperatives of productivity, and indeed in the very fact of creating with such devotion a structure for the veneration of two Sufi saints. Shrines organise heterodox devotional practices in Pakistan: ecstatic dancing and singing, the solicitation of miracles and the distribution of amulets ( $\left.t a^{\prime} w i z\right)$ to ward off evil. The famous shrine of Ali Hajveri in Lahore, Data Darbar, is renowned as a place where the saint will answer prayers or provide guidance. For these same reasons shrines

\footnotetext{
${ }^{93}$ Declan Walsh, 'Of Saints and Sinners', The Economist (18 December 2008).

${ }^{94}$ I am grateful to Umber bin Ibad for conversation on this point. See also his Sufi Shrines and the Pakistani State (London, 2018).
} 
draw the wrath of orthodox Islamic groups, and on occasion have been violently attacked by groups like the Pakistani Taliban, Data Darbar included. As Muhammad Qasim Zaman notes, it is often the built form that is targeted as much as the people gathered there..$^{95}$ Mumtaz's building should thus be understood as a riposte not merely to modern architecture but also to Islamist understandings of religious expression.

The shrine in Baghbanpura is intended to demonstrate an alternative way of inhabiting the world and the slow, ongoing process of construction is central to this. The mausoleum is animated by that vital link between the craftsmen, the community they belong to, and the place where they work and dwell. Mumtaz, echoing Heidegger's approach to craft, contrasts this complex of relationships with serial production or mass manufacture, which breaks from context and community to produce interchangeable 'objects', alienated labour and "images of the self which are illusions". ${ }^{96}$ There are clear similarities between Mumtaz's thought and Heidegger's diagnosis of the 'crisis of dwelling' in modernity. This is unsurprising, considering the influence Heidegger's writings had on architectural theory and education in the 1970s and 80s, as the profession reoriented practice around ideas of context, atmosphere and the spirit of place. ${ }^{97}$ While Mumtaz told me that he never engaged with Heidegger's writings directly, his career took form in an international circuit deeply affected by them. The German philosopher's anti-technocratic stance has found sympathetic advocates

\footnotetext{
95 Zaman, Islam in Pakistan, 223-24.

96 Mumtaz, Modernity, 35; and see Martin Heidegger, Bremen and Freiburg Lectures, trans. Andrew J Mitchell (Bloomington, 2012), 34-5.

${ }^{97}$ Adam Sharr, Heidegger for Architects (London: Routledge, 2007).
} 
among liberals and conservatives alike, his entanglements with Nazism notwithstanding. But in drawing these comparisons it is important to situate Mumtaz amidst a generation's disillusionment with organised left politics in Pakistan, their search for an alternative after sustained domestic repression and a changing international order. Many of the architect's contemporaries turned to questions of culture, poetry and literature to explore themes of resistance, freedom and the dignity of work. Mumtaz's turn to craft can be seen in similar terms. While a critique of capitalism remains tangible in his public interventions, the possibility of radical change is defused by a perennialist concern for balance and harmony: a retreat from politics as the idea of innovation to one that is about mitigating excess and deferring to the wisdom of traditional order.

In Mumtaz's deference to Sufi spiritual principles, his understanding that success arrives only as the "fulfillment of pure intentions", the architect allows a place for God in the process of making and building. ${ }^{98}$ This is explicit in a story he tells of the mosque project in Pak Wigah. A huge amount of marble carving was required for the design, but problems with the on-site masonry workshop were causing significant disruption. At a moment of desperation, Mumtaz describes, “a miracle happened":

One hundred stonecarvers materialized out of nowhere to take up the work. Twice a week, they appear after dark and work through the night. The site is ablaze with powerful lights. The music of hymns and chants playing over the loudspeakers all but drowns the din of more than forty power tools. The air is filled with marble dust that turns everything chalky white - white hair, white faces with cut-out liquid eyes and tracks of joyful tears running down the cheeks. At the break of dawn, the work stops, the carvers say their morning prayers in congregation, and then disperse. Washed and changed, they step into the day as ordinary

\footnotetext{
98 Samina Quraeshi's 'Introduction' to Sacred Spaces, xi-xii.
} 
teachers, lawyers, paramedics, and shopkeepers and go about their daily routines. ${ }^{99}$

Accepting this space for divine intervention risks underplaying human agency, but while Mumtaz is open to serendipity he does not rely on the miraculous, and has frequently assumed the position of campaigner and advocate in his career. I want to conclude now by turning to his heritage activism in Lahore, and its relation to some of the ideas of disposability, history and recursive temporality discussed above.

The miraculous energy mustered at Pak Wigah is notable for its absence otherwise in popular interactions with Pakistan's built environment, according to Mumtaz. The ethics of a craft tradition - patience, durability, care - are rarely observed, marginalised by a resilient appetite for the new which is reflected in twenty-first century Lahore's glass towers, concrete viaducts and sprawling shopping malls. His pessimism about the protection of historic architecture in the country is palpable in conversation. A long career of organising conservation campaigns and consciousness-raising initiatives has provided little fuel for hope. Mumtaz is currently President of the Lahore Bachao Tehreek (Lahore Conservation Society, lit. 'Save Lahore Movement'), an organisation established in the 1980s with the mission to "undertake and promote...the protection, conservation, and improvement of the physical environment of Lahore"100. This group of "concerned citizens" looks particularly to fill a gap left by the

\footnotetext{
${ }^{99}$ Mumtaz, "Architecture of Sufi Shrines", 60.

100 'Our Mission', http://www.lcs.org.pk. The LCS was initiated in 1984 by the architect Zahir-ud Deen Khawaja, supported by others including the architect Nayyar Ali Dada and human rights advocate IA Rehman.
} 
government in their disinterest in problems of historical preservation - or, in cases where they are interested, to prevent rush jobs, 'overrestoring', and the use of incorrect materials. The Anjuman Mimaran, similarly, was involved in restoration work in Lahore's Walled City, at the Haveli Sayyida Mubarak Begum and elsewhere. The careful and precise work of restoration aligns with Mumtaz's ideas of learning through copying, 'realizing' forms that had previously existed. It is a practice that instills knowledge through work, rather than through mere observation. Heritage consciousness, for Mumtaz, requires a change in value systems - it is a question of humanity and of environment, "not the academic's need for authenticity, not the aesthete's enjoyment of beauty, not the tourist's demand for the quaint and picturesque, not the nationalist's need for glory, not the zealot's craving for a place in heaven, and least of all not the satiation of the market's hunger for profit."101

In 2014 , the value of Lahore's built heritage was subject to unprecedented public debate, prompted by construction work for a new rapid mass transit system. The Orange Line Metro project, funded by soft loans from the Chinese government and built in collaboration with Chinese contractors, cuts through the heart of the city, requiring the destruction of several buildings and even entire neighborhoods in its path. The scheme attracted controversy not simply for these evictions but also for an idea that the completed Metro will spoil the scenic vistas of old Lahore: that it will compromise and therefore condemn "the entire cultural landscape" of the city. ${ }^{102}$ Activists highlighted eleven historical sites

101 Kamil Khan Mumtaz, "Sustainable Cultural Tourism”, The Friday Times (25 July 2004) 102 “UN urges Pakistan to halt construction of Orange Metro Train”, Daily Times (25 January 2016). 
threatened by proximity to the path, stretching from the Shalimar Bagh to the tomb of Zeb-un-Nisa.

Opposition to the Orange Line has been criticised for reflecting 'elite' views of what is culturally valuable, foregrounding questions of heritage over human lives and wellbeing - the necessity of better public transport provision in one of Pakistan's largest cities - but the issue is not so clear cut. In the first place, it presumes an appreciation of historic architecture is restricted to certain social groups, and as Shaila Bhatti's ethnography of the Lahore Museum has shown, heritage assets draw interest across Pakistan's social spectrum. ${ }^{103}$ More specifically, Mumtaz, as spokesperson for an alliance of citizens groups, has consistently centred the relationship between heritage and the welfare of communities. An August 2016 petition to Lahore High Court - which was successful in temporarily suspending construction of the Orange Line - did not focus simply on aesthetic implications of the Metro but connected the heritage argument to the well-being of Lahore's vulnerable or marginalised communities, criticising the government's acquisition of land from citizens by "hook or by crook", and the pursuit of a "white elephant" for "cheap publicity". ${ }^{104}$ Mumtaz here animates his long-standing critique of the state's pursuit of development, understood less as an attempt to 'improve' Pakistani society than as a means to accumulate prestige and demonstrate sovereign power.

The failure of campaigns like \#RastaBadlo ('Change the Route') has taken a toll on Mumtaz. The state appears as his key antagonist, so hypnotised by the

${ }^{103}$ Shaila Bhatti, Translating Museums (Walnut Creek, CA, 2012).

104 “Construction on Lahore’s Orange Line Metro Train to be suspended: LHC," Dawn, August 19 2016. 
desire to emulate Shanghai or Dubai that it is ready to destroy that which makes Lahore distinctive - unless of course those distinctions can be mobilised for tourism and economic growth. In 2018, he communicated this vision of a benighted political elite to me with a joke. The Orange Line debacle could be summarised, he said, in a statement attributed to Punjab's then-Chief Minister Shehbaz Sharif, expressing his frustration with the protests of heritage campaigners: "What are these guys going on about, eleven historic sites? We will make hundreds of historic sites! The Chinese will help us - China is very good at it!"105 For Mumtaz, the corruption of the developmental mindset is here complete: 'heritage' is simply another form of entertainment or commodity that can be mass produced and even imported.

But all is not lost. Mumtaz sees the seeds of a popular heritage consciousness in the way that people interact with tombs and particularly Sufi mazaars. In contrast to mosques, which are not 'consecrated' in the manner of Christian churches and as such can be restructured or removed entirely depending on need, tombs are tied - via the presence of the dead - to the significance of place. Mumtaz tells me that in fact they may "suffer from too much love", referring to the decoration of popular sites with lights and other ornaments, glorifying the spirit dwelling within. But the building is appreciated as an object of permanence and singular significance. It orientates the world

\footnotetext{
105 Interview with Mumtaz, Lahore, 12 February 2018. The joke derives from a spoof news site: see 'Shahbaz vows to construct new heritage sites along OMLT route', The Daily Khabaristan (20 August 2016), accessed online at https://dailytimes.com.pk/62454/satire-shahbaz-vows-toconstruct-new-heritage-sites-along-olmt-route/. I am grateful to Timothy Cooper for this reference.
} 
around it. The tomb thus demonstrates an ethic of cultivation, upholding continuity against disposability, imagining structures as vital to a community and acknowledging that, though people dwell in buildings, so must the spirits of the dead, with all the histories they carry.

I began this article by noting how the creation of Pakistan in 1947 posed some compelling problems for thinking about time and history. My interest was not in attempts to forge national identity out of a vacuum, but in what conceptual innovations this condition of an 'uncertain historicity' might provoke, specifically in the realm of professional architecture. For Kamil Khan Mumtaz, who navigated a period in which both modernists and Islamists advocated a rupture with the past, towards the creation of a new world, the prospect of a building practice grounded in regional codes and sensitive to cultural contexts promised a way out of the twentieth-century's crisis of dwelling. But rather than simply deploying traditional forms or using local materials and technologies, Mumtaz departed from the tropical modernists, critical regionalists and vernacular ornamentalists of his generation to place an emphasis on the craft and process of building itself, and in particular the relationship of this process to time, productivity and spirituality. I have noted how this path was informed both by disillusionment with leftist politics in Pakistan and by an interest in the esoteric dimensions of Islam, filtered through a reading of perennialist philosophy. The ethic of dwelling that emerges from Mumtaz's historical research and building work is a powerful one, but one that remains marginalised in contemporary Pakistan and which, in its commitment to old order and hidden harmonies, cannot ally easily with projects for a radical realignment of the society that prompted it. In our twenty-first century present, cluttered with the debris of 
divisive but intensely felt histories, facing futures of scarcity and the increased mobility of populations, problems of cultivation and preservation have become ever more pressing. Mumtaz's recursive reasoning mirrors global calls for order, balance and 'slowness' in a time of ecological crisis. But whether or not such practices can withstand the mounting pressures of the present without an experimental, generative dimension remains a crucial debate for our times. 